\title{
Identification of phosphate transporter NaPi2b as MX35 cancer antigen by modified SEREX approach
}

\author{
R. G. Kiyamova, V. S. Gryshkova, V. S. Usenko, Y. S. Khozaenko ${ }^{1}$, V. A. Gurtovyy ${ }^{1}$, \\ B. Yin'², G. Ritter ${ }^{2}$, L. Old ${ }^{2}$, I. T. Gout ${ }^{3}$, V. V. Filonenko
}

Institute of Molecular Biology and Genetics, National Academy of Sciences of Ukraine 150 Zabolotnogo Str., Kyiv 03680, Ukraine

${ }^{1}$ BIONTEC

52A/88 Komsomol'ska Str., Dnipropetrovs'k, 49000, Ukraine

${ }^{2}$ Ludwig Institute for Cancer Research, New-York branch at Memorial Sloan-Kettering Cancer Center 1275 York Avenue, BOX 32 New York, NY 10021-6007, USA

${ }^{3}$ Department of Biochemistry and Molecular Biology, University College London Gower Street, London WC1E6BT, UK

r.g.kiyamova@imbg.org.ua

\begin{abstract}
In this study we describe the identification of sodium-dependent phosphate transporter NaPi2b as MX35 cancer-associated antigen. To achieve this goal we have screened extensively a cDNA expressing library from ovarian cancer cell line OVCAR3 with monoclonal antibody MX35. To further confirm the authenticity of this finding, we showed that bacterially and baculovirally expressed NaPi2b is specifically recognized by MX35 antibody. Moreover, the validity of these results was verified in a parallel study involving affinity purification and mass spectrometry. The epitope for MX35 monoclonal antibody was mapped to the largest extracellular loop of NaPi2b. Taken together, this study uncovers the identity of MX35 antigen and provides molecular tools for studying its function in normal and cancer tissues.
\end{abstract}

Keywords: MX35 monoclonal antibodies, ovarian cancer, sodium-dependent phosphate cotransporter $\mathrm{NaPi} 2 \mathrm{~b}$

Introduction. The identification and molecular characterization of tumor-associated markers and antigens is central for the development new diagnostic and therapeutic interventions in cancer. Monoclonal antibody technology was exploited extensively in 1970s for the identification of antigens that distinguish normal cells from cancer cells and could be used as diagnostic markers or as targets for immunotherapy. Mouse monoclonal antibody MX35 was developed

\footnotetext{
(C) R. G. KIYAMOVA, V. S. GRYSHKOVA, V. S. USENKO,

Y. S. KHOZAENKO, V. A. GURTOVYY, B. YIN, G. RITTER,

L. OLD, I. T. GOUT, V. V. FILONENKO, 2008
}

more than 20 years ago by immunizing mice with ovarian carcinoma cells and designated screening for tumor-associated antigens. Further analysis indicated that MX35 antigen is overexpressed in $80 \%$ cases of human epithelial ovarian cancer, but shows restricted expression in normal tissues. Biochemical and immunohistochemical studies revealed that MX35 $\mathrm{mAb}$ recognizes cell surface glycoprotein of about $95 \mathrm{kDa}$ which is overexpressed in $80 \%$ ovarian cancer specimens [1]. Moreover, MX35 antigen was found to be stabilized by disulfide bond formation [2]. 
Clinical studies with Fab fragments of radiolabeled MX35 antibody suggest therapeutic potential in patients with ovarian cancer [3]. Ovarian cancer is the most common gynecologic malignancy that usually becomes far advanced before it is diagnosed. Therefore, it is associated with poor prognosis and survival rate. So far, only few tumor-associated markers and antigens specific for ovarian cancer have been identified. Undoubtedly, MX35 antigen is one of them. However, the progress on studying the function of MX35 antigen in normal and cancer cell lines or tissues has been held back by unknown molecular identity of this antigen.

Here we describe the identification of MX35 antigen as sodium-dependent phosphate transporter $\mathrm{NaPi} 2 \mathrm{~b}$. For this purpose, we performed extensive screening of OVCAR-3 expression library with MX35 $\mathrm{mAb}$. Molecular identity of MX35 antigen was further confirmed by immunoblotting of bacterially and baculovirally expressed NaPi2b with MX35 antibody. The identification of MX35 antigen as NaPi2b opens broad perspectives for future studies, especially on establishing the link between phosphate homeostasis, cellular metabolism, and cancer growth.

Materials and Methods. Cell lines and antibodies. All cell lines used in this study were obtained from the cell bank of the Ludwig Institute for Cancer Research, New York Branch at Memorial Sloan-Kettering Cancer Center. Murine mAb MX35 (IgG1) was purified from hybridoma supernatant by protein $\mathrm{G}$ chromatography.

Immunoscreening of OVCAR-3 expression library. cDNA expression library from OVCAR-3 cell line was constructed using ZAP Express ${ }^{\circledR}$ cDNA Synthesis Kit and ZAP Express ${ }^{\circledR}$ cDNA Gigapack III Gold Cloning Kit («Stratagene», USA). A total of $1 \cdot 10^{6}$ recombinant phages were screened with MX35 monoclonal antibody. For the primary screening, XL-1 Blue MRF cells were infected with $6 \cdot 10^{3}$ phage particles, mixed with top agarose and plated onto $150 \mathrm{~mm}$ Petri dishes. The expression of recombinant proteins was induced by the addition of $1 \mathrm{mM}$ IPTG. The transfer of the proteins to the nitrocellulose membrane Hybond-C was carried out overnight at $37{ }^{\circ} \mathrm{C}$. The membranes were then blocked with $5 \%$ non-fat dried milk (NFDM) for $1 \mathrm{hr}$ at room temperature and incubated with $\mathrm{MX} 35 \mathrm{mAb}$ $(5 \mu \mathrm{g} / \mathrm{ml}$, in $0.2 \% \mathrm{NFDM} / \mathrm{TBS})$ for $15 \mathrm{hrs}$ at room temperature. After washing in TBS, the membranes were incubated with alkaline phosphatase conjugated Fc-fragment specific goat anti-human IgG («Sigma», USA) and processed for 4-nitro blue tetrazolium chloride/5-bromo-4-chloro-3-indolil-phosphate color development. Positive clones were extracted from agar and stored in $0.5 \mathrm{ml}$ of SM buffer $(0.1 \mathrm{M} \mathrm{NaCl}, 10 \mathrm{mM}$ $\mathrm{MgSO}_{4}, 50 \mathrm{mM}$ Tris- $\mathrm{HCl}, 0.01 \%$ gelatine) containing $20 \mu \mathrm{l}$ chloroform. MX35 positive clones were subjected to secondary screening as described above. Isolated positive phages were converted into $p B K-\mathrm{CMV}$ phagemid using in vivo excision protocol («Stratagene», USA). Rescued plasmid DNAs were purified according to manufacturer's instruction («Qiagen», USA) and subjected to restriction analysis and DNA sequencing.

Cloning, expression, and purification of GST/NaPi2b fusion proteins in bacteria. A cDNA fragment, corresponding to the largest extracellular loop (ECL) of human NaPi2b cotransporter (188-361 a) was PCR amplified and cloned into $p G E X 4 T 1$ vector in frame with GST. Briefly, EcoRI and BamHI restriction sites were introduced at the $5^{\prime}$ and $3^{\prime}$ of PCR amplified NaPi2b DNA fragments respectively. The expression of GST/NaPi2b-L fusion protein in BL21 DE3 cells was induced by $1 \mathrm{mM}$ IPTG for $3 \mathrm{hrs}$ at $37{ }^{\circ} \mathrm{C}$. Cells were harvested by centrifugation and disrupted by sonication in lysis buffer $(25 \mathrm{mM}$ Tris $\mathrm{HCl}, \mathrm{pH} 7.5,150 \mathrm{mM} \mathrm{NaCl}, 1 \mathrm{mM}$ EDTA, $0.5 \%$ Triton and protease inhibitor cocktail («Boehringer Mannheim», Germany). Purification of GST-NaPi2b-L from the insoluble fraction was performed using electro-elution from the gel. The purity of eluted GST/NaPi2b-L was analyzed by SDS-PAGE electrophoresis.

Expression and purification of His/NaPi2b-L protein in baculoviral system. A cDNA fragment, corresponding to the ECL of human NaPi2b cotransporter (188-361 aa) was PCR amplified and subcloned into pFastBac-His vector using EcoRI and BamHI sites. The recombinant baculovirus was generated using Bac-to-Bac expression system («Invitrogen», USA). Sf9 insect cells growing in IPL41 medium (10\% FBS, 50 units $/ \mathrm{ml}$ penicillin and $50 \mu \mathrm{g} / \mathrm{ml}$ streptomycin) were infected with recombinant His/NaPi2b-L baculovirus for 3 days. Collected cells 
were lysed in buffer containing $50 \mathrm{mM}$ Tris $\mathrm{HCl}, \mathrm{pH}$ $8.5,100 \mathrm{mM} \mathrm{KCl}, 5 \mathrm{mM} \beta$-mercaptoethanol, $1 \% \mathrm{NP} 40$, $1 \mathrm{mM}$ PMSF, $10 \mathrm{mM}$ benzamidine, $1 \mu \mathrm{g} / \mathrm{ml}$ pepstain. The lysates were then centrifuged at $10000 \mathrm{rpm}$ for 15 min and clarified supernatant probed with Ni-NTA sepharose for 1 hour at $4{ }^{\circ} \mathrm{C}$. Affinity purification of His/NaPi2b-L protein on Ni-NTA sepharose was performed according to manufacturer's recommendations («Qiagen»). The quality of purified His/NaPi2b-L was analyzed by SDS-PAGE electrophoresis.

Western-blot analysis. For immunoblotting, purified recombinant proteins or cell lysates were separated by SDS-PAGE and transferred onto PVDF membrane. The membrane was blocked for $1 \mathrm{hr}$ in PBST (PBS with $0.05 \%$ Tween 20) and incubated overnight at $4{ }^{\circ} \mathrm{C}$ with MX35 antibodies $(1 \mu \mathrm{g} / \mathrm{ml})$. After washing three times in PBST the membrane was incubated with anti-mouse IgG antibody («Promega», USA) at 1:2000 dilutions for 2 hrs. Finally, the membranes were washed with PBST and probed with chemiluminescence reagent (ECL, «Amersham Biosciences», UK) for $2 \mathrm{~min}$, and then exposed to the $\mathrm{X}$-ray film.

Antibody depletion procedure. $50 \mu \mathrm{g}$ of MX35 Mab was diluted in $2.5 \mathrm{ml} \mathrm{PBST}$ and incubated with $100 \mu \mathrm{l}$ of Glutathione Sepharose coupled with $0.5 \mathrm{mg}$ GST/NaPi2b-L or GST alone overnight at $4{ }^{\circ} \mathrm{C}$. Unbound fractions of mAbs were used for immunohistochemical analysis of ovarian cancer samples according to standard protocol.

Immunohistochemistry. Representative sections of ovarian tumors were prepared from paraffin blocks. Endogenous peroxidase was quenched with $\mathrm{H}_{2} \mathrm{O}_{2}(3 \%)$ in methanol. After blocking of non-specific staining with avidin-biotin blocking solution (Vector Laboratories, Burlinghame, CA, USA), tissue sections were incubated overnight at $4{ }^{\circ} \mathrm{C}$ with MX35 mAb $(10$ $\mu \mathrm{g} / \mathrm{ml}$ ) and MX35 mAb depleted against GST/NaPi2B-L or GST alone. Then, sections were incubated with biotinylated secondary antibodies for 2 $\mathrm{hrs}$ at room temperature (1:400, goat anti-mouse biotinylated IgG, «Sigma»), followed by the addition of avidin-biotin-peroxidase compex (Vector Laboratories, Burlinghame, CA, USA; $30 \mathrm{~min}$, room temperature) and the development with diaminobenzidine solution. Haematoxylin was used for counterstaining. The sections were examined using Zeiss Universal microscope («Zeiss», Germany).

Bioinformatics. CLUSTALW (1.82) software (www.ebi.ac.uk/clustalw/) was used for multiple sequence alignment of DNA and protein sequences from MX35 positive clones. B-cell epitope prediction software (www.imtech.res.in/raghara/bcepred) was used for predicting MX35 epitope.

Results and Discussion. The search for MX35 antigen was carried out in the frame of a collaborative consortium involving research laboratories from the Ludwig Institute for Cancer Research (New York and Uppsala Branches) and the Institute of Molecular Biology and Genetics. To identify MX35 antigen, we employed a modified version of SEREX methodology (Serological identification of recombinantly expressed clones). We have used this methodology extensively to search for novel tumor-associated antigens in various types of human cancer [4-7]. Taking into account that MX35 antigen is expressed at high level in ovarian cancer and ovarian cancer cell line OVCAR-3 in particular, the expression library from OVCAR-3 cells was generated and probed with MX35 monoclonal antibody as described in Material and Methods. Screening of $1.10^{6}$ plagues with affinity purified MX35 IgGs allowed us to isolate a panel of weakly positive clones. Second- and third-round screenings confirmed specificity towards MX35 mAb only for three clones, which we termed RK1, RK4, and RK6. The immunoreactivity of RK1 positive clone in primary and secondary screenings is shown in Fig. 1, $A$ and $B$ (see plating). Following excision from the phagemid, the cDNA inserts from rescued plasmids were analysed using restriction digestion and DNA sequencing. Bioinformatic analysis of obtained sequences revealed that RK1 clone encodes sodium-dependent phosphate transporter NaPi2b (AF146796), while clones RK4 and RK6 possess overlapping sequences of zinc-finger protein 638 (BC083513) (Fig. 1, C, see plating, Fig. 2, $A$, see plating). Literature-based analysis of both proteins indicated that sodium-dependent phosphate transporter NaPi2b (also known as NaPi3b, Npt2, SLC34A2) exhibits significant similarities to MX35 antigen. First of all, NaPi2b is a cell-surface glycoprotein $\left(\begin{array}{lll}690 & \text { aa }\end{array}\right)$ with approximately 8 transmembrane domains (SMART, Uniprot T-KB 

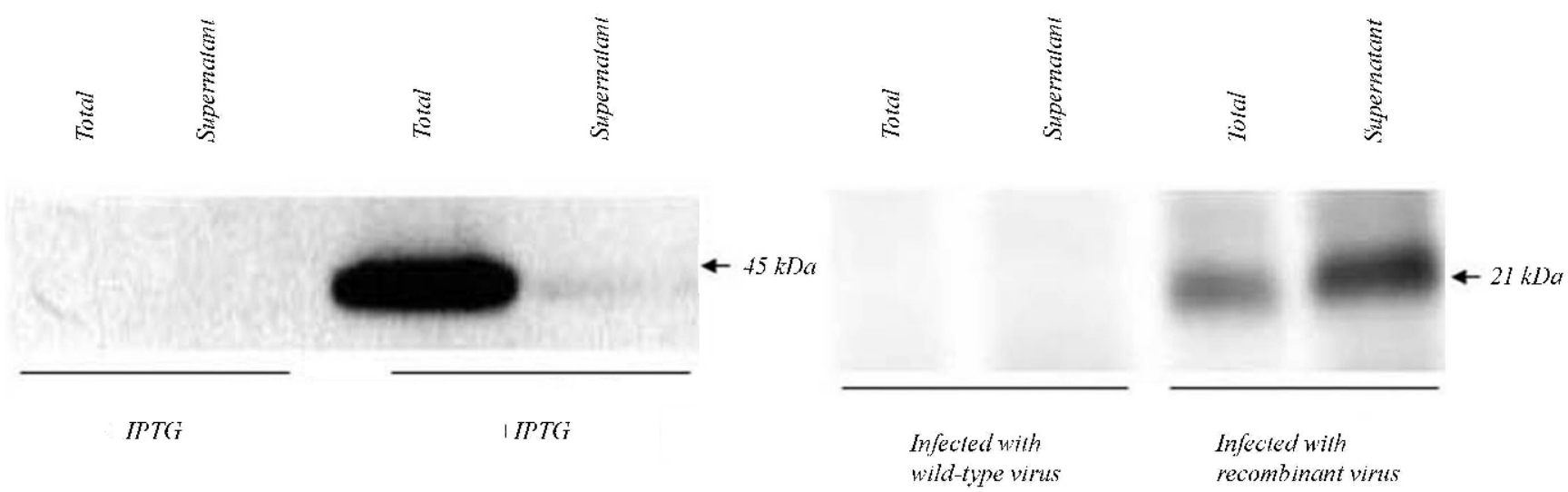

Fig. 3. $A$ - expression of GST/NaPi2b-ECL in bacteria was induced by $1 \mathrm{mM}$ IPTG. Total lysates and soluble fractions were resolved by SDS-PAGE and probed with MX35 mAb; $B$ - Sf9 cells were infected with recombinant baculovirus which drives the expression of His/NaPi2b-ECL or wild type virus. Total lysates and soluble fractions of infected cells were resolved by SDS-PAGE and immunoblotted with MX35 mAb

database). Secondly, similar to MX35 antigen fully glycosylated form of $\mathrm{NaPi} 2 \mathrm{~b}$ runs on SDS-PAGE as a $95 \mathrm{kDa}$ protein [8]. Moreover, $\mathrm{NaPi} 2 \mathrm{~b}$ has a predicted basic charge 13.0 (Bioinformatic harvester database) while MX35 antigen does not bind to DEAE sephadex column suggesting its basic charge as well [2]. Finally, $\mathrm{NaPi} 2 \mathrm{~b}$ and MX35 antigen exhibit similar patterns of expression at protein and mRNA level in normal and cancer tissues $[1,9]$. In contrast to $\mathrm{NaPi} 2 \mathrm{~b}$, zinc-finger protein 638 shows nucleocytoplasmic localization and exhibits different biochemical properties and expression profiles when compared to MX35 antigen [10]. The function of this protein is proposed to be involved in packaging, transferring, and processing of mRNA transcripts. Interestingly, zinc-finger protein 638 is also known as a CTCL tumor antigen se33-1 or cutaneous T-cell lymphoma associated antigen se 33-1.

Taking this into account, we decided to further investigate the specificity of $\mathrm{NaPi} 2 \mathrm{~b}$ recognition by MX35 antibody using various bioinformatic and experimental approaches. Sequence analysis and alignment of type II family of sodium-dependent phosphate transporters suggest that $\mathrm{NaPi} 2 \mathrm{~b}$ might possess 8 transmembrane domains mostly located within two $\mathrm{Na}^{+} / \mathrm{Pi}$ cotransporter domains, while both the $\mathrm{N}$ - and $\mathrm{C}$-terminal regions face intracellular compartment. The topology of potential transmembrane domain implies the existence of a large extracellular loop located between transmembrane domains 3 and 4 [11]. Since MX35 mAb recognizes the antigen on the surface of immunoreactive cells, one may predict the location of the MX35 epitope within one of the extracellular loops of NaPi2b. To check this assumption, we have expressed the largest extracellular loop of NaPi2b (188-361 aa) in bacterial and baculoviral system with GST and His-tag respectively. The expression of recombinant GST/NaPi2b-ECL in bacteria and His/NaPi2b-ECL in insect cells was confirmed by immunoblotting with anti-GST or anti-His-tag antibodies (unpublished data). When expressed in bacteria, GST/NaPi2b-ECL is found mainly in the insoluble fraction, while baculovirally produced His/NaPi2b-ECL shows very good solubility. Initially, we probed the lysates of bacterial cells expressing GST alone or GST/NaPi2b-ECL with MX35 mAb. The data presented in Fig. 3, A, a indicate clearly that immunoreactive band of approximately 45 $\mathrm{kDa}$ is specifically recognized with MX35 mAb in cells expressing GST/NaPi2b-ECL, but not GST alone. Notably, the molecular weight of GST/NaPi2b-ECL is around $45 \mathrm{kDa}$. Then, we demonstrated that baculovirally expressed His/NaPi2b-ECL is also recognized by MX35 antibody (Fig. 3, B). Notably, the molecular weight of GST/NaPi2b-ECL is around 45 
$\mathrm{kDa}$ while the molecular weight His/NaPi2b-ECL is around $21 \mathrm{kDa}$. Taken together, these results provide strong evidence that $\mathrm{NaPi} 2 \mathrm{~b}$ is a strong candidate for MX35 antigen and that the epitope is located within the largest extracellular loop. Moreover, the identification of $\mathrm{NaPi} 2 \mathrm{~b}$ as a potential MX35 antigen in the expression screening was further confirmed by affinity purification followed by mass spectrometry analysis [12].

The results of $2^{\text {nd }}$ and $3^{\text {rd }}$ round screening undoubtedly demonstrated that MX35 mAb recognition of RK4 and RK6 clones was specific, but much weaker when compared to RK clone. These results suggest that all three clones possess sequences which correspond or are highly homologous to MX35 epitope. To test this assumption, we aligned amino acid sequences from the largest extracellular loop of $\mathrm{NaPi} 2 \mathrm{~b}$ and zinc-finger protein 638 using ClustalW software. This analysis allowed us to identify a region which exhibited very high level of homology between two proteins (Fig. 2, B, see plating). Further studies are required to map the epitope for MX35 antibody more precisely.

As mentioned above, MX35 is overexpressed in ovarian cancer. Therefore, we employed immunohistochemical approach to examine staining of ovarian carcinoma samples with MX35 mAb under various experimental conditions, including depletion of MX35 $\mathrm{mAb}$ immunoreactivity with recombinant $\mathrm{NaPi} 2 \mathrm{~b}$. As shown in Fig. 4, $A$ (see plating), the apical surface of ovarian carcinoma is strongly stained with MX35 mAb. However, pretreatment of MX35 mAb with the access of GST/NaPi2b-ECL, as described in Materials and Methods, abolished the immunoreactivity of the depleted sample in ovarian carcinoma (Fig. 4, $B$, see plating). When GST alone was used for depletion of MX35 mAb, no significant changes in the strength of immunoreactive signal in ovarian carcinoma samples was observed (unpublished data). These findings provided further evidence that $\mathrm{NaPi} 2 \mathrm{~b}$ might function as a tumor-associated antigen in ovarian cancer and that MX35 epitope is localized in the extracellular loop of $\mathrm{NaPi} 2 \mathrm{~b}$. We have recently developed a panel of monoclonal antibodies towards recombinant ECL of NaPi2b (188-361 aa), which recognize endogenous antigen in various immunological assays [13] and that may be further developed as novel immunotherapeutic agents to treat cancer.

As a member of type II family of sodium-dependent phosphate transporters, $\mathrm{NaPi} 2 \mathrm{~b}$ has been implicated in maintaining cellular homeostasis of inorganic phosphate in various organs, including lungs, testis, liver, salivary glands, secreting mammary gland, osteoblasts, etc. [9, 14-18]. The transporting function of $\mathrm{NaPi} 2 \mathrm{~B}$ is tightly controlled by mitogens, glucocorticoids, vitamins, and metabolic factors [8, 19-25]. Deregulation of NaPi2b activity has been recently associated with pulmonary and testicular microlithiasis [26]. So far, there are only few reports linking NaPi2b to malignant growth. The studies involving DNA microarrays and SAGE analysis found $\mathrm{NaPi} 2 \mathrm{~b}$ to be overexpressed in ovarian and papillary thyroid cancer $[27,28]$. The identification of $\mathrm{NaPi} 2 \mathrm{~b}$ as a potential MX35 cancer-associated antigen should give further incentives for the investigation on the role of this transporter in the regulation of cell growth, proliferation, and survival in health and cancer.

Acknowledgments. This study was supported in part by grants from the National Academy of Sciences of Ukraine and the Kerr Program, the Ludwig Institute for Cancer Research. R. Kiyamova was supported by short term fellowship from FEBS for conducting this study.

Р. Г. Кіямова, В. С. Гришкова, В. С. Усенко, Ю. С. Хожаєнко, В. А. Гуртовий, Б. Вин, Г. Риттер, Л. Олд, І. Т. Гут,

В. В. Філоненко

Ідентифікація фосфатного транспортера $\mathrm{NaPi} 2 \mathrm{~b}$ як пухлинного антигену MX35 3 використанням модифікованого методу SEREX

Резюме

Натрій-залежний транспортер $\mathrm{NaPi2b}$ ідентифіковано як МХЗ5 пухлинний антиген. Для иього здійснено скринування кДНК-експресуючої біблеотеки, отриманої з клітин OVCAR3, моноклональними антитілами МХ35. Щоб підтвердити иі дослідження, встановлено, щчо NaPi2b, експресований в бактеріях та клітинах комах, специфічно розпізнається МХЗ5 антитілами. Крім того, виявлено ділянку, яка містить епітоп для моноклональних антитіл на великому позаклітинному домені NaPi2b. Таким чином, нами визначено антиген МХ35, щзо забезпечує молекулярну основу для подальшого вивчення його функиії в нормальних тканинах та при раку.

Ключові слова: моноклональні антитіла МХ35, рак яєчників, фосфатний натрій-залежний котранспортер $\mathrm{NaPi2b}$. 
Р. Г. Киямова, В. С. Гришкова, В. С. Усенко, Ю. С. Хожаенко, В. А. Гуртовой, Б. Вин, Г. Риттер, Л. Олд, И. Т. Гут, В. В. Филоненко

Идентификация фосфатного транспортера $\mathrm{NaPi} 2 \mathrm{~b}$ как опухлевого антигена МХ35 с использованием модифицированного метода SEREX

Резюме

Натрий-зависимый транспортер NaPi2b идентифицирован как МХ35 опухлевый антиген. Для достижения этого осуществлено скринирование кДНК-экспрессирующей библиотеки, полученной из OVCAR3 клеток, моноклональными антителами. Чтобы подтвердить эти результаты, установлено, что $N a P i 2 b$, экспрессированный в бактериях и в клетках насекомых, специфично узнается антителами МХ35. Определен участок на внеклеточном домене $\mathrm{NaPi2b,} \mathrm{содержащий} \mathrm{эпитоп} \mathrm{для}$ антител. Таким образом, нами идентифицирован антиген МХ35, что создает молекулярную основу для дальнейшего изучения его функции в нормальных и раковых тканях.

Ключевые слова: моноклональные антитела МХ35, рак яичников, фосфатный натрий-зависимый котранспортер $\mathrm{NaPi2b.}$

\section{REFERENCES}

1. Mattes M. J., Look K., Furukawa K., Pierce V. K., Old L. J., Lewis J. L., Lloyd K. O. Mouse monoclonal antibodies to human epithelial differentiation antigens expressed on the surface of ovarian carcinoma ascites cells // Cancer Res.-1987.-47, N 24.-P. 6741-6750.

2. Welshinger M., Yin B. W., Lloyd $K$. $O$. Initial immunochemical characterization of MX35 ovarian cancer antigen // Gynecol. Oncol.-1997.-67, N 2.-P. 188-192.

3. Finstad C. L., Lloyd K. O., Federici M. G., Divgi C., Venkatraman E., Barakat R. R., Finn R. D., Larson S. M., Hoskins W. J., Humm J. L. Distribution of radiolabeled monoclonal antibody MX35 F(ab')2 in tissue samples by storage phosphor screen image analysis: evaluation of antibody localization to micrometastatic disease in epithelial ovarian cancer// Clin. Cancer Res.-1997.-3.-P. 1433-1442.

4. Garifulin O. M., Kykot V. O., Gridina N. Y., Kijamova R. G., Gout I. T., Filonenko V. V. Application of SEREX-analysis on colon cancer cases // Exp. Oncol.-2003.-25, N 2.P. 128-131.

5. Kyyamova R. G., Rodnin N. V., Garifulin O. M., Tykhonkova I. A., Koroveva E. P., Gout I. T., Filonenko V. V. Allogenic screening of tumor antigenes from thyroid cancer cDNA libraries // Biopolymers and Cell.-2003.-18, N 6.-P. 23-25.

6. Scanlan M. J., Chen Y. T., Williamson B., Gure A. O., Stockert E., Gordan J. D., Tureci O., Sahin U., Pfreundschuh M., Old L. J. Characterization of human colon cancer antigens recognized by autologous antibodies // Int. J. Cancer.-1998.-76, N 5.-P. 652-658.

7. Scanlan M. J., Gure A. O., Jungbluth A. A., Old L. J., Chen Y. $T$. Cancer/testis antigens: an expanding family of targets for cancer immunotherapy // Immunol. Revs.-2002.-188.P. 22-32.

8. Xu H., Bai L., Collins J. F., Ghishan F. K. Age-dependent regulation of rat intestinal type IIb sodium-phosphate cotransporter by $1,25-(\mathrm{OH})_{2}$ vitamin D3 // Amer. J. Physiol. Cell Physiol.-2002.-282, N 3.-P. 487-493.
9. Field J. A., Zhang L., Brun K. A., Brooks D. P., Edwards R. $M$. Cloning and functional characterization of a sodium-dependent phosphate transporter expressed in human lung and small intestine // Biochem. and Biophys. Res. Communs.-1999.-258, N 3.-P. 578-582.

10. Eichmueller S., Usener D., Dummer R., Stein A., Thiel D., Schadendorf $D$. Serological detection of cutaneous T-cell lymphoma-associated antigens // Proc. Nat. Acad. Sci. USA.-2001.-98, N 2.-P. 629-634.

11. Murer H., Foster I., Biber J. The sodium phosphate cotransporter family SLC34 // Pflugers Arch.-2004.-447, N 5.-P. 763-767.

12. Yin B. W. T., Kiyamova R., Chua R., Caballero O. L., Gout I., Gryshkova V., Bhaskaran N., Souchelnytskyi S., Hellman U., Filonenko V., Jungbluth A. A., Odunsi K., Lloyd K. O., Old L. $J$, Ritter G. Monoclonal antibody MX35 detects the membrane transporter $\mathrm{NaPi} 2 \mathrm{~b}$ (SLC34A2) in human carcinomas; a new target for cancer immunotherapy // Cancer Immunol.-2008.-8.-P. 3-12.

13. Kiyamova R., Gryshkova V., Ovcharenko G., Lituyev D., Malyuchik S., Usenko V., Khozhayenko Y., Gurtovyy V., Yin B., Ritter G., Old L., Filonenko V., Gout I. Development of monoclonal antibodies specific for the human sodium-dependent phosphate cotransporter NaPi2b // Hybridoma.-2008.-In press.

14. Traebert M., Hattenhauer O., Murrer H., Kaissling B., Biber $J$. Expression of type II Na-P(i) cotransporter in alveolar type II cells // Amer. J. Physiol.-1999.-277, N 5.-P. 868-873.

15. Homann V., Rosin-Steiner S., Stratmann T., Arnold W. H., Gaengler P., Kinne R. K. Sodium-phosphate cotransporter in human salivary glands: molecular evidence for the involvement of NPT2b in acinar phosphate secretion and ductal phosphate reabsorption // Arch. Oral. Biol.-2005.-50, N 9.-P. 759-768.

16. Xu Y., Yeung C.-H., Setiawan I., Avram C., Biber J., Wagenfeld A., Lang F., Cooper T. G. Sodium-inorganic phosphate cotransporter $\mathrm{NaPi}$-IIb in the epididymis and its potential role in male fertility studied in a transgenic mouse model // Biol. Reprod.-2003.-69, N 4.-P. 1135-1141.

17. Frei P., Gao B., Hagenbuch B., Mate A., Biber J., Murer H., Meier P. J., Stieger B. Identification and localization of sodium-phosphate cotransporters in hepatocytes and cholangiocytes of rat liver // Amer. J. Physiol. Gastrointest. Liver Physiol.-2005.-288, N 4.-P. 771-G778.

18. Lundquist P., Murer H., Biber J. Type II $\mathrm{Na}^{+}-\mathrm{P}$ cotransporters in osteoblast mineral formation; regulation by inorganic phosphate // Cell Physiol. Biochem.-2007.-19, N 1-4.P. 43-56.

19. Hattenhauer O., Traebert M., Murer H., Biber J. Regulation of small intestinal $\mathrm{Na}-\mathrm{Pi}$ type IIb cotransporter by dietary phosphate intake // Amer. J. Physiol. Gastrointest. Liver Physiol.-1999.-277, N 4 (pt 1).-P. 756-G762.

20. Xu H., Uno J. K., Inouye M., Xu L., Drees J. B., Collins J. F., Ghishan F. K. Regulation of intestinal NaPi-IIb cotransporter gene expression by estrogen // Amer. J. Physiol. Gastrointest. Liver Physiol.-2003.-285, N 6.-P. 1317-1324.

21. Arima K., Hines E. R., Kiela P. R., Drees J. B., Collins J. F., Ghishan F. K. Glucocorticoid regulation and glycosylation of mouse intestinal type $1 \mathrm{lb} \mathrm{Na}-\mathrm{Pi}$ cotransporter during ontogeny // Amer. J. Physiol.-2002.-283, N 2.-P. 426-434.

22. Miyamoto K., Ito M., Kuwahata M., Kato S., Segawa H. Inhibition of intestinal sodium-dependent inorganic phosphate transport by fibroblast growth factor $23 / /$ Ther. Apher. Dial.-2005.-9, N 4.-P. 331-335. 
23. Xu H., Collins J. F., Bai L., Kiela P. R., Ghishan F. K. Regulation of the human sodium-phosphate cotransporter $\mathrm{NaPi}-11 \mathrm{~b}$ gene promoter by epidermal growth factor // Amer. J. Physiol.-2001.-280, N 3.-P. 628-636.

24. Palmada M., Dieter M., Speil A., Bohmer C., Mack A. F., Wagner H. J., Klingel K., Kandolf R., Murer H., Biber J., Closs E. L., Lang F. Regulation of intestinal phosphate cotransporter $\mathrm{NaPi}$ IIb by ubiquitin ligase Nedd4-2 and by serum- and glucocorticoid-dependent kinase $1 / /$ Amer. J. Physiol. Gastrointest. Liver Physiol.-2004.-287, N 1.P. 143-150

25. Shojaiefard M., Lang $F$. Stimulation of the intestinal phosphate transporter SLC34A2 by the protein kinase mTOR // Biochem. and Biophys. Res. Communs.-2006.-345, N 4.P.1611-1614.
26. Corut A., Senyigit A., Ugur S. A., Altin S., OzcelikU., Calisir H., Yildirim Z., Gocmen A., Tolun A. Mutations in SLC34A2 cause pulmonary alveolar microlithiasis and are possibly associated with testicular microlithiasis // Amer. J. Hum. Genet.-2006.-79, N 4.-P. 650-656.

27. Rangel L. B., Sherman-Baust C. A., Wernyj R. P., Schwartz D. R., Cho K. R., Morin P. J. Characterization of novel human ovarian cancer-specific transcripts (HOSTs) identified by serial analysis of gene expression // Oncogene.-2003.-22, N 46.-P. 7225-7232.

28. Jarzab B., Wiench M., Fujarewicz K., Simek K., Jarzab M., Oczko-Wojciechowska M., Wloch J., Czarniecka A., Chmielik E., Lange D., Pawlaczek A., Szpak S., Gubala E., Swierniak $A$. Gene expression profile of papillary thyroid cancer: sources of variability and diagnostic implications // Cancer Res.-2005.-65, N 4.-P. 1587-1597.

УДК $577.2,577.27$

Надійшла до редакції 10.10.07 